Journal of Biotechnology and Strategic Health Research

\author{
Research Article / Araştırma Makalesi
}

http://dergipark.org.tr/tr/pub/bshr

\title{
Akut Gastroenteritli Hastalarda İnsan Bokavirüsün Moleküler Yöntem ile Araştırılması
}

\section{Molecular Detection of Human Bocavirus (HBoV) in Stool Samples in Patients with Acute Gastroenteritis}

\section{(iD) Fadime Kahyaoğlu' ${ }^{1}$ (iD $\square$ Sevin Kırdar}

${ }^{1}$ Celal Bayar Üniversitesi, Tip Fakültesi, Histoloji ve Embriyoloji Anabilim Dalı, Manisa

${ }^{2}$ Adnan Menderes Üniversitesi, Tip Fakültesi, Tibbi Mikrobiyoloji Anabilim Dalı, Aydın

ORCID ID: Sevin Kırdar, https://orcid.org/0000-0002-4511-578X, Fadime Kahyaoğlu, https://orcid.org/0000-0002-5149-8051

`Sorumlu Yazar / Corresponding Author: Prof. Dr. Sevin KIRDAR, e-posta / e-mail: sevin.kirdar@gmail.com

Geliş Tarihi / Received: 28-07-2020 Kabul Tarihi / Accepted: 14-10-2020 Yayın Tarihi / Online Published: 31-12-2020

Atıf Gösterimi/How to Cite: Kırdar S., Kahyaoğlu F. Akut Gastroenteritli Hastalarda İnsan Bokavirüsün Moleküler Yöntem ile

Araştırılması, J Biotechnol and Strategic Health Res. 2020;4(3):256-261

Özet

Amaç Akut gastroenteritler tüm dünyada özellikle çocuk yaş grubunda daha fazla olmak üzere morbidite ve mortalitenin en önemli nedenlerinden biridir. Gastroenterit etiyolojisinin ve epidemiyolojisinin bilinmesi, etkin tedavi uygulanmasının yanı sıra gereksiz antibiyotik kullanımının önlenmesini ve ayrıca hastalık etkenleri ile mücadeleyi sağlamaktadır. Gastroenterite neden olan viral patojenler; rotavirus (RV), norovirus (NoV), sapovirus (SaV), adenovirus (AdV), astrovirus (AstV) ve bokavirus (BoV)'dur. Bu çalışmada Aydın ilinde akut gastroenteritli hastalarda insan BoV (HBoV) sıklığının ve tiplerinin moleküler yöntem ile araştırılması amaçlandı.

Materyal ve Çalışmaya Eylül 2013 ile Ekim 2014 tarihleri arasında hastanemize başvuran akut gastroenteritli 44 (\%46)’ ü kadın, 52 (\% 54)’ si erkek olmak üzere toplam 96 hastaya

Metod ait dışkı örneği dahil edildi. İnsan BoV-DNA’sı NS-1 gen bölgesine uygun primer dizilerinin kullanıldığı real-time (gerçek zamanlı) polimeraz zincir reaksiyonu (PZR) yöntemi ile araştırıldı. Bokavirus tiplendirilmesi tipe özgül real-time (gerçek zamanlı) PZR yöntemi ile ve koenfeksiyon varlğ̆ ise multipleks PZR ile belirlendi.

Bulgular Çalıșmada incelenen 96 dıșkı örneğinin 2'sinin (\% 2) HBoV pozitif olduğu belirlendi. Pozitif iki örnek, tipe özgül gerçek zamanlı PZR ile HBoV tip 1 olarak bulundu. Diğer bokavirus tipleri saptanmadı. İnsan BoV tip 1 pozitif hastalar erkek cinsiyetinde ve 0- 2 yaş grubundaydı. İki hastada rotavirus ile koenfeksiyon gözlendi.

Sonuç Bu çalıșma ile akut gastroenteritli hastalarda etiyolojik ajan olarak bokavirusun da diğer sıklıkla saptanan viruslar gibi gastroenterite neden olabileceği belirlenmiștir. Gastroenteritlerde viral etkenlerin belirlenmesi, gereksiz antibiyotik kullanımının önlenmesini hem hasta maliyetini hem de patojenlerin antibiyotiklere karșı direnç geliștirmesini azaltacaktır.

Anahtar İnsan bokavirus, gastroenterit, dışkı, real-time PZR

kelimeler

Aim Acute gastroenteritis is the most important causes of morbidity and mortality, especially in children worldwide. To know the factors that cause gastroenteritis enables effective treatment as well as prevent the use of unnecessary antibiotics. Viral pathogens that cause gastroenteritis; rotavirus (HRV), norovirus (HNoV), sapovirus (HSaV), adenovirus (HAdV), astrovirus (HAst $V)$ and bocavirus $(\mathrm{BoV})$. The aim of study was to investigate the frequency and types of $\mathrm{HBOV}$ in patients with gastroenteritis by molecular methods in Aydin province.

Material and Between September 2013 and October 2014, a total 96 patients who were admitted to our hospital with stool samples were included. Forty four of patients were female and 52 were male.

Method BoV-DNA was investigated by real-time PCR appropriate to NS-1 gene region. The typing of HBoV was determined by type-specific PCR and the coinfection of the other viruses was determined by multiplex $P C R$

Results Two (2\%) of the 96 samples were determined to be HBoV positive. Two samples with positive were determined as HBoV type 1 by type specific real-time PCR. Other types of HBoV not detected. The positive patients for HBoV type 1 were 0-2 years old and male gender. Mixed infection with RV were observed in 2 (100\%) patients.

Conclusion it was determined that bocavirus as an etiological agent in patients with acute gastroenteritis may cause gastroenteritis like other frequently detected viruses. The identification of viral agents in gastroenteritis will reduce both the cost of preventing unnecessary antibiotic use and the development of resistance to antibiotics in pathogens.

Key words Human Bocavirus, gastroenteritis, stool, real time PCR 


\section{GIIRIŞ}

İshal tüm dünyada çocuk yaş grubunda morbidite ve mortalitenin en önemli nedenlerinden biridir. Özellikle beş yaş altı çocuklarda ishal, gelişmekte olan ülkeler ile Afrika’da mortalitenin üçüncü en büyük nedenidir'. Akut gastroenteritin en önemli bulgularından biri olan ishal akut dehidratasyona, neden olduğu malnutrisyon çocuklarda büyümenin etkilenmesine ve gereksiz antibiyotik kullanımına yol açması nedeni ile önem taşımaktadır². Viruslar, özellikle çocuk yaş grubunda, gastroenteritin en önemli nedeni olup rotavirus, norovirus, astrovirusus ve adenovirus en sık saptanan viruslar olarak kabul edilmektedir. Son zamanlarda insanlarda ishal ile ilişkili viral ajanların sayısı giderek artmaktadır1. Gastroenterit ile ilişkili yeni viruslardan biri olan insan bokavirüs (HBoV) ilk kez 2005 y1lında Allander ve arkadaşları tarafından alt solunum yolu enfeksiyonu gözlenen çocukların solunum yolu örneklerinden belirlenmiş ${ }^{3}$ ve 2007 yllından bu yana gastroenteritli çocukların dışkı örneklerinde etken olarak dünyanın değişik bölgelerinden birçok çalışmada gösterilmiştir ${ }^{4-12}$. Filogenetik analiz ile bokavirusların HBoV1-4 olmak üzere 4 alt tipden oluştuğu bildirilmiştir³. İnsan BoV1 sıklıkla çocuklarda solunum yolu hastalıkları ile ilişkili olup, aynı zamanda gastrointestinal semptomlarla da ilişkilidir ${ }^{3,12}$. İnsan BoV2, BoV3 ve BoV4 sıklıkla dışkı örneklerinde nadiren solunum yolunda görülmektedir ${ }^{7,13,14}$. İnsan bokavirus tip 2 ilk kez Pakistan'da gevşek paralizli hastaların dışkı örneklerinden izole edilirken, Avustralya'da HBoV2 yanı sıra HBoV3 izole edilmiştir ${ }^{14}$. Bu çalışmada hastanemize akut gastroenterit tanısı ile başvuran hastaların dışkı örneklerinde real time (gerçek zamanli) polimeraz zincir reaksiyonu yöntemi ile $\mathrm{HBoV}$ varlığının ve genotiplerinin araştırılmasını amaçlanmıştır. Ayrıca bokavirus pozitif bulunan hasta örneklerinde viral koenfeksiyon varlığı için diğer sık karşılaşılan gastroenterit etkeni viruslar multipleks PZR yöntemi ile araştırılmıştır.

\section{YÖNTEM}

Eylül 2013-Ekim 2014 tarihleri arasında Adnan Menderes Üniversitesi Uygulama ve Araştırma Hastanesi Çocuk
Hastalıkları Polikliniği ve Acil Servisten Tıbbi Mikrobiyoloji Anabilim Dalı Laboratuvarına akut gastroenterit kuşkusu ile gönderilen 44 (\%46)' ü kadın, 52 (\% 54)'si erkek olmak üzere toplam 96 hastaya ait dışkı örneği çalışmaya dahil edildi. Hastalardan alınan dışkı örnekleri dışkı kapları içinde çalışılıncaya kadar $-80^{\circ} \mathrm{C}$ de saklandı.

Hastaların yaş ortalaması 4 yıl (0-79) olarak belirlendi ve $\% 51$ 'i 0-24 ay grubunda yer almaktaydı. Hastaların yaş dağllımı Tablol'de gösterilmiştir. Hastalar rastgele seçildi ve çalışma prospektif olarak yürütüldü. Çalışmada Tibbi Etik Kurul Yönergesine göre hastaların bilgilendirilmiş onaylar1 alındı (ADÜ-Girişimsel Olmayan Klinik Araştırmalar Etik Kurulunun 11.09.2013 tarih ve 56989545/050.04-198 sayılı etik kurul kararı).

Dışkı örneklerinden DNA izolasyonu QIAampR Fast DNA Stool Mini Kit (Qiagen, Hilden, Almanya) ile üretici firmanın önerdiği talimatlaraa göre yapıldı. $\mathrm{HBoV}$ varlığ1 ORF bölgesinden kodlanan NS-1 gen bölgesine uygun primer dizileri (Pan-HBoV-F; ATA AAG TTC CAA ACT CAT TTC CTC TTG Pan-HBoV-R; AGT GCA GWA TCC GTT TTC GTG (88 bp) kullanılarak belirlendi. Amplifikasyon için $200 \mu$ l'lik PZR tüplerine $0.6 \mu$ distile su, 0.2 $\mu \mathrm{l}$ forward primer $(0.4 \mu \mathrm{M}) 0.2 \mu \mathrm{l}(0.4 \mu \mathrm{M})$ revers primer ve $5 \mu$ enzim karışımı (2x)'indan oluşan $6 \mu$ PCR karış1mı ve $4 \mu$ l DNA eklendi. Amplifikasyon, LightCycler 480 (Roche, Almanya) cihazında $95^{\circ} \mathrm{C}$ 'de 15 saniye denatürasyon, $55^{\circ} \mathrm{C}$ 'de 15 saniye bağlanma ve $72^{\circ} \mathrm{C}$ 'de 10 saniye uzama olmak üzere 40 siklus sonunda $60^{\circ} \mathrm{C}$ 'de 45 saniye ekstansiyon aşamaları ile gerçekleştirildi8. Pozitif örneklerin kantitatif sonuçları "absolute 25 quantitation second derivative" analizi kullanılarak "ct" değerleri ile cihaz tarafindan otomatik olarak hesaplandı. Doğrulama amacıyla çoğaltılan PZR ürünleri \%2 oranında hazırlanan agaroz jelde görüntülendi. Çalışmanın sınırlı bütçesi nedeniyle referans köken sağlanamadığı için pozitif kontrol olarak solunum yolu örneklerinde $\mathrm{HBoV}$ pozitif bulunan ve viral yükleri sırasıyla 4.106 (PK1) ve 4.102 (PK2) kopya/ml. olan iki klinik örnek kullanıldı. 
J Biotechnol and Strategic Health Res. 2020;4(3):256-261

KAHYAOĞLU, KIRDAR, İnsan Bokavirüsün Moleküler Yöntem ile Araştırılması

Bokavirus pozitif örneklerin genotiplendirilmesi için özgül HBoV 1-4 primerleri [HBoV1: F; TCTCCGGCGAGTGAACATC ve RT1; CAT CCG GAT GAG GAG CGC (226 bç); HBoV2:F;TCTCCGGCGAGTGAACATCveRT2primerGCTCTTCCTCTTTCCAGTTTTC(149bç);HBoV3:F;TCTCCGGCGAGTGAACATCveF;TCTCCGGCGAGTGAACATC;HBoV4:F;TCTCCGGCGAGTGAACATCveRT4;GCCAATTTCAGACTGGCAAAC

$(384$

bp)] kullanılarak real time PZR yöntemi ile gerçekleştirildi ve pozitif örnekler melting analizi ile değerlendirildi.

Koenfeksiyon varlığı, diğer sık karşılaşılan gastroenterit etkeni virüsleri [enteric adenovirus (EAV), astrovirus $(\mathrm{AsV})$, rotavirus grup A (RV grup A) ve norovirus (NoV) genogrup I ve II] belirleyebilen Seeplex ${ }^{\circledR}$ Diarrhea ACE Detection multiplex PZR system (Seeplex system; Seegene, Korea) kiti ile üretici firmanın talimatlarına göre araştırıldi.

\section{BULGULAR}

İnsan BoV varlığının tüm tipleri belirleyen pan-primerleri kullanılarak real time PZR yöntemi ile yapılan bu çalışmada 2 (\%2) dışkı örneğinde pozitiflik saptanmıştır. İnsan BoV saptanan örneklere ait amplifikasyon eğrileri şekil 1'de ve doğrulama amaciyla yapılan elektroforez sonucu pozitif saptanan hastalara ait jel görüntüsü şekil 2' de gösterilmiştir. Pozitif saptanan iki örnekte tipe özgül real time PZR yöntemi ile HBoV tip 1 belirlenmiştir. Bu iki örneğin viral yükleri birinci hastada $6.103 \mathrm{kopya} / \mathrm{ml}$, ikinci hastada $4.102 \mathrm{kopya} / \mathrm{ml}$ olarak belirlenmiştir. $\mathrm{HBoV}$ tip 1 pozitif hastalar 0-2 yaş grubunda ve erkek cinsindeydi (Tablo 1). Hastaların her ikisi de solunum yolu enfeksiyon bulguları olmaksızın ishal ve kusma yakınmaları ile hastaneye başvurmuştur.

Çalışmada yer alan hasta örneklerinde viral koenfeksiyon varlığı multipleks PZR yöntemi ile araştırılmış ve $\mathrm{HBoV}$ tip 1 saptanan 2 hastada rotavirus ile miks enfeksiyon belirlenmiştir.

\begin{tabular}{|c|c|c|c|}
\hline \multirow[t]{2}{*}{ Hasta Yaş Gruplar n(\%) } & \multicolumn{2}{|c|}{ HBoV PCR } & \multirow{2}{*}{$\frac{\text { HBoV Tip } 1}{\begin{array}{c}\text { Pozitif } \\
\text { saptanan }\end{array}}$} \\
\hline & Pozitif & Negatif & \\
\hline $0-12$ ay, $\quad 17(17.7)$ & $2^{*}$ & 15 & 2 \\
\hline $2-12 y, \quad 16(16.7)$ & 0 & 16 & - \\
\hline $13-24 y, \quad 16(16.7)$ & 0 & 16 & - \\
\hline $25-60 y, \quad 36(37.5)$ & 0 & 16 & - \\
\hline$\geq 60$ y ve üstü, 11(11.4) & 0 & 11 & - \\
\hline \multicolumn{4}{|l|}{${ }^{*}$ Erkek cinsinde } \\
\hline
\end{tabular}

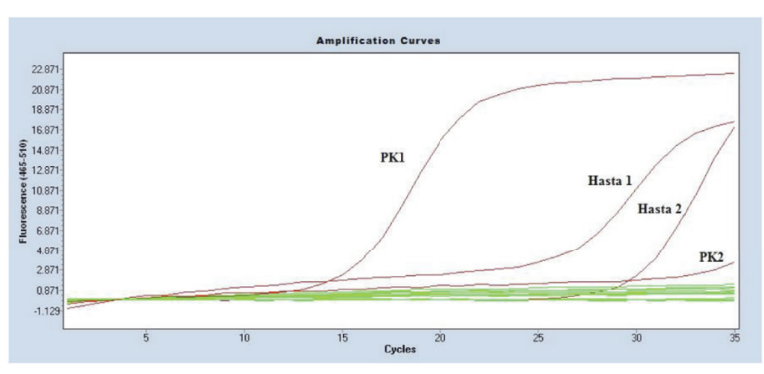

Şekil 1. HBoV pozitif saptanan hastaların amplifikasyon eğrileri

PK1, PK2: pozitif kontroller

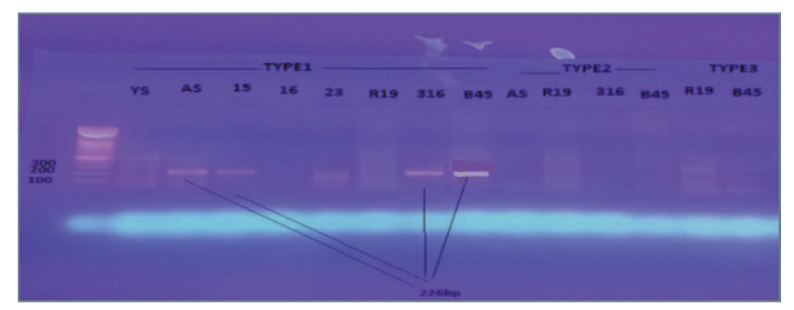

Şekil 2. Tipe özgül real-time PZR ile pozitif HBoV Tip 1 saptanan hastaların agaroz jel görüntüsü. 316, B45: pozitif kontroller; AS, 15: hastalar

\section{TARTIŞMA}

Akut gastroenterit gelişmekte olan ülkelerde çocuklarda morbidite ve mortalite nedenlerinden biridir. Günümüzde çocukluk çağında akut gastroenteritlere neden olan etkenlerin çoğu viruslardır15. Allender ve ark. tarafından HBoV'un tanımlanmasından sonra, 2007 yılından sonraki çalışmalarda gastrointestinal semptomlar gösteren çocukların dışkı örneklerinde yaygın olarak pozitiflik saptanmış 
ve bu virusun gastroenterite yol açtı̆̆ fikrinin ortaya atılmasını sağlamıştır. Vicente ve ark.'nın İspanyảda yaptıkları çalışma ile, ilk kez akut gastroenteritli çocukların dışkı örneklerinde $\mathrm{HBoV}$ pozitifliği bildirilmiş ve 527 hastanın 48'inde (\%9,1) HBoV saptanmıştır. Yapılan bu çalışmada, pozitiflik oranının yüksek bulunması akut gastroenterit olgularında etken olabileceğini düşündürmüştür ${ }^{5}$.

Akut gastroenteritli hastaların dışkı örneklerinde $\mathrm{HBoV}$ prevalansı \%0.8 ile \%24 arasında değişmektedir ${ }^{4,69-11,16-18}$. $\mathrm{HBoV}$ prevalansının \%42 ve \%46 gibi çok yüksek oranlarda saptandığını bildiren çalışmalar da bulunmaktadır8,15. Bokavirus çalışmalarında saptanma oranlarının bu değişkenliğin nedeni bokavirusun saptanma yöntemlerindeki farklılığa bağlı olabilir. Hastanemize başvuran akut gastroenterit tanılı hastalara ait 92 dışkı örneğinin dahil edildiği çalı̧̧mamızda 2 (\%2) örnek $\mathrm{HBoV}$ pozitif olarak saptanmıştır. Belirlediğimiz bu oran Brezilya (\%2), HongKong (\%2.1), ve İtalya (\%2)'da yapılan çalışmalardaki 4,12,20 oranlar ile benzer, Kore (\%0.18) ve Meksika (\%1.3)'dan18,19 bildirilen oranlardan daha yüksek, Arnavutluk (\%9.1) ve Çin(\%17.3)'de bulunan oranlardan daha düşük bulunmuştur ${ }^{10,21}$.

Ülkemizde, HBoV ile ilgili solunum yolu enfeksiyonu etkeni olarak gösterildiği çalışmalar yanı sıra akut gastroenterite neden olduğunu gösteren çalışmalar da bulunmaktadır9, 22-24. Gastroenterit ile ilişkili iki çalışmadan birinde; Mitui ve ark. beş yaş altındaki akut ishalli çocuklarda yaptıkları çalışmada, Bangladeş’ten 138 ve Türkiyéden 150 olmak üzere toplam 288 dışkı örneğini incelemişler ve $\mathrm{HBoV}$ pozitifliğini sırasıyla 87 (\%63) ve 13 $(\% 8,7)$ olarak bulmuşlardır'. Sirekbasan ve ark. 0-5 yaş arası çocuklardaki akut gastroenteritlerde $\mathrm{HBoV}$ varlığ ve sıklı̆̆ının araştırdıkları çalışmalarında 101 dışkı örneğinden $7(\% 6.9)$ sinde $\mathrm{HBoV}$ pozitifliği saptamışlardır²4. Çalışmamızda belirlediğimiz \%2'lik oran bu iki çalışmaya göre daha düşük olarak bulunmuştur. Bokavirusa bağlı akut gastroenteritler özellikle iki yaş altında olmak üzere en fazla çocuklarda görülmesinin yanında, erişkinlerde de saptanabilir ${ }^{14}$. Çalışmamızda da HBoV pozitif saptanan 2 olgunun yaşları iki yaş altında olup, çocuklarda özellikle iki yaş altı çocuklarda bokavirusun daha sık belirlendiği çalışmalara benzer bulunmuştur ${ }^{4,25,26}$. Çalışmada $\mathrm{HBoV}$ tip-1 iki erkek hastada bulunmuş ve HBoV'ün cinsiyet ile ilişkisinin değerlendirildiği diğer çalışmalarda erkek hastalarda kadın hastalara oranla daha yüksek oranlarda görüldüğü bildirilmiştir ${ }^{12,27}$. Tüm dünyada semptomatik hastalarda $\mathrm{HBoV}$ tiplerinin prevalansı, $\mathrm{HBoV}$ tip 1 için \%1.5-94. $8^{10,17,18,25,27}$, HBoV tip 2 için \%2.6-48 ${ }^{6,9,18}$ arasında değişirken, HBoV tip 3 \%1.6-2.6 ${ }^{18,28}$ ve HBoV tip 4 için $\% 3.2^{28}$ olarak saptanmıştır. Akut gastroenteritli hasta örneklerinde HBoV1'in diğer tiplerden daha fazla oranlarda görüldüğünü bildiren çalışmaların ${ }^{10,18,25}$ yanısıra $\mathrm{HBoV}$ 2'nin diğer tiplere oranla daha yüksek oranlarda saptandığ ${ }_{1}$ çalışmalar da bulunmaktadır ${ }^{6,9}$. Çalışmamızda HBoV pozitif bulunan iki örneğin tipe özgül real-time PZR ile tiplendirilmesi sonucunda ikisinin de $\mathrm{HBoV}$ tip 1 olduğu belirlenmiş ve Zhang ve ark' nın Çin' de, Lee ve ark Kore'de ve Netshikweta ve ark.'nın Güney Afrika'da yaptıkları çalışmalar ile benzer bulunmuştur ${ }^{27,29,30}$. Bununla birlikte Proenca-Modena ve ark.'ları HBoVtip1'in gastroenteritdeki rolünün hala belirsiz olduğunu, $\mathrm{HBoV}$ tipl'in aslında solunum yolunda çoğaldığını ve yutulan nazofaringeal sekresyonların dışkıda virusun kontaminasyon kaynağı olabileceğini ileri sürmüşlerdir ${ }^{31}$.

Çalışmamızda viral koenfeksiyon varlığı multipleks PZR yöntemi ile araştırılmış ve $\mathrm{HBoV}$ saptanan 2 hastada rotavirus ile miks enfeksiyon belirlenmiştir. Bokavirusa bağlı gastroenteritlerde koenfeksiyon oranları \%60-\%90 arasında değiştiğ $1^{14}$ ve koenfeksiyonların araştırıldığ çalışmalarda, $\mathrm{HBoV}$ ile en fazla rotavirus olmak üzere norovirus ile koenfeksiyon belirlendiği bildirilmiştir ${ }^{10,18,22,25}$. Çalışmamızda Arnavutluk, Pakistan, Çin ve Brezilyada yapılan çaıışmalara benzer şekilde en fazla rotavirus ile koenfeksiyon belirlenmiştir ${ }^{10,18,27}$.

Gastroenterite neden olan HBoV enfeksiyonun mevsimlerle ilişkisi tüm dünyada farklılıklar göstermektedir ve 
J Biotechnol and Strategic Health Res. 2020;4(3):256-261

en fazla sonbahar ve kış aylarında daha yüksek oranlarda görülmektedir ${ }^{12,16}$ Pakistanda yapılan bir çalışmada ${ }^{25}$ kışın ve ilkbaharın sonunda (özellikle Ocak ve Mayıs ayında pik yaptığı) ve Çin'de yapılan bir çalışmada yaz ve ilkbaharın başında daha yüksek oranda saptandığı bildirilmiştir ${ }^{21}$. Çalışmamızda HBoV saptanan hastaların önceki çalışmalara benzer şekilde sonbaharda hastaneye başvurdukları belirlenmiştirr ${ }^{12,16}$. Sonuç olarak, bu çalışma ile akut gastroenteritli hastalarda bokavirusun da rotavirus, norovirus, adenovirus tip 40/41, astrovirus gibi gastroenterite neden olabileceği belirlenmiştir. İnsan BoV’un akut gastroenteritlerdeki rolüne yönelik yapılan çalışmalar tedavi ve epidemiyolojik açıdan çok önemlidir. Günümüzde daha çok solunum yolu enfeksiyonu olan çocuklarda saptanmış olan bu virusun gastrointestinal sistem enfeksiyonlarındaki rolü ile ilişkili çalışmaların az sayıda olması nedeniyle ülkemizdeki önemi bilinmemektedir. Bu nedenle bu virusun çocukluk çağı gastroenteritlerindeki rolünü belirlemek amacıyla daha fazla moleküler ve epidemiyolojik çalışmalara gereksinim vardır. Ayrıca gastroenteritlerde diğer viral etkenler gibi bokavirusun belirlenmesi de gereksiz antibiyotik kullanımının önlenmesini hem maliyeti hem de patojenlerde antibiyotiklere karşı direnç gelişimini azaltabilecektir. Bunun yanında genotip belirleme gibi virolojik özelliklerinin ortaya konulması hastalıkların patogenez, klinik özellikleri ve tanı stratejilerinin belirlenmesine yardımcı olabilecektir. Bu çalışma, Fadime Kahyaoğlu'nun yüksek lisans tez yayınıdır ve Aydın Adnan Menderes Üniversitesi Bilimsel Araştırma Projeleri Koordinatörlüğü tarafından TPF-14042 proje numarası ile desteklenmiş ve 16-18 Kasım, 2017 tarihinde Bulgaristan (Sofya)'da düzenlenen X. Balkan Kongresi'nde poster bildiri olarak sunulmuştur, üçüncülük ödülü almıştır. 
J Biotechnol and Strategic Health Res. 2020;4(3):256-261

\section{Kaynaklar}

1. Rikhotso MC, Kabue JP, Ledwaba SE, et al. Prevalence of Human Bocavirus in Africa and Other Developing Countries between 2005 and 2016: A Potential Emerging Viral Pathogen for Diarrhea. J Trop Med 2018, 12: 7875482.

2. Özkan A, Çocukluk çağı akut gastroenterit olgularında etiyolojik ajanların belirlenmesi. Uzmanlık tezi. Çukurova Üniversitesi Tip Fakültesi, Çocuk Sağlı̆̆ı ve Hastalıkları Anabilim Dal, Adana, Türkiye-2005.

3. De R, Liu L, Qian Y, et al. Risk of acute gastroenteritis associated with Human bocavirus infection in children:A systematic review and meta-analysis. PLoS One 2017;12(9):e0184833.9

4. Albuquerque MC, Rocha $L N$, Benati FJ, et al. Human bocavirus infection in children with gastroenteritis, Brazil. Emerg Infect Dis 2007;13(11):1756-8.

5. Vicente D, G. Cilla, M. Montes, et al. Human bocavirus, a respiratory and enteric virus. Emerg Infect Dis 2007; 13 (4,): 636-7.

6. Arthur Higgins GD, Davidson GP, Givney RC, et al. A novel bocavirus associated with acute gastroenteritis Australian children.PLoSPathogens doi.org/10.1371/journal.ppat.1000391.

7. Kapoor A, Simmonds P, Slikas B, et al. Human bocaviruses are highly diverse, dispersed, recombination prone, and prevalent enteric infections. J Infect Dis 2010 1; 201(11): 1633-43.

8. Nawaz S, Allen DJ, Aladin F, et al. Human bocaviruses are not significantly associated with gastroenteritis: results of retesting archive DNA from a case control study in the UK. PLoS One 2012; 7 :e41346 doi: 10.1371/journal.pone.0041346.

9. Mitui MT, Bozdayi G, Ahmed S, et al. Detection and molecular characterization of diarrhea causing viruses in single and mixed infections in children: a comparative study between Bangladesh and Turkey. J Med Virol 2014 Jul;86(7):1159-68.

10. La Rosa G, Della Libera S, Laconelli $M$, et al. Human bocavirus in children with acutegastroenteritis in Albania. J Med Virol 2016; 88(5): 906-10.

11. Lee JI, Chung JY, Han TH, et al. Detection of human bocavirus in children hospitalized because of acute gastroenteritis. J Infect Dis, 2007; 196(7): 994-7.

12. Lau SK, Yip CC, Que TL, et al. Clinical and molecular epidemiology of human bocavirus in respiratory and fecal samples from children in Hong Kong. J Infect Dis 2007; 196: 986-93.

13. Chow BD, Ou Z, Esper FP. Newly recognized bocaviruses (HBoV, HBoV2) in children and adults with gastrointestinal illness in the United States. J Clin Virol 2010; 47: 143-47.

14. Schildgen O. Human Bocavirus: Lessons learned to date; Pathogens 2013, 2:1-12.

15. Campos GS, Sampaio MLS, Menezes ADL, et al. Human Bocavirus in Acute Gastroenteritis in Children in Brazil. J Med Virol 2016; 88:166-70.

16. Romani S, Mohebbi SR, Khanyaghma M, et al. Detection of Human Bocavirus 1, 2 and 3 from patients with acute gastroenteritis. Gastroenterology Hepatology from Bed to Bench 2013; 6:77-81.

17. Kim S. Prevalence of human bocavirus 1 among people without gastroenteritis symptoms in South Korea between 2008 and 2010. Arch Virol 2014;159 (10):2741-4.
18. Soares LS, Lima AB, Pantoja KC, et al. Detection and Molecular Epidemiology of Human Bocavirus in Children with Acute Gastroenteritis from Brazil. BioRxiv doi: https://doi. org/10.1101/404632.

19. Martínez MA, Soto-Del Río Mde L, et al. DNA microarray for detection of gastrointestinal viruses. J Clin Microbiol 2015; 53: 136-45.10

20. Rovida F, Campanini G, Piralla A, et al. Molecular detection of gastrointestinal viral infections in hospitalized patients. Diagn Microbiol Infect Dis 2013; 77: 231-5.

21. Zhou T, Chen Y, Chen J, et al. Prevalence and Clinical profile of human bocavirus in children with acute gastroenteritis in Chengdu, West China, 2012-2013. J Med Virol 2017; 89(10):1743-48

22. Midilli K, Yllmaz G, Türkoğlu S, ve ark. Akut solunum yolu enfeksiyonlu çocuk ve eriskinlerde insan bokavirus DNA'stnin polimeraz zincir reaksiyonu ile saptanmast. Mikrobiyol Bul, 2010; 44: 405-13.

23. Uyar M, Kuyucu N, Tezcan S, ve ark. Bronșiyolit Tanısı Alan 0-2 Yaş Grubu Çocuklarda Insan Bokavirus ve Diğer Solunum Viruslarının Siklğı̆nın Arașttrılması. Mikrobiyol Bul 2014; 48(2):242-58.

24. Sirekbasan S, Midilli K, Akın Y, ve ark. Akut gastroenteritli çocuklarda human Bocavirus DNA varlı̆̆ını arașttrılması. Turk Hij Den Biyol Derg 2017;74(4): 261-68.

25. Alam MM, Khurshid A, Shaukat S, et al. Human bocavirus in Pakistani children with gastroenteritis. J Med Virol 2015; 87: 656-63.

26. Wang Y, Gonzalez R, Zhou H, et al. Detection of human bocavirus 3 in China. European Journal of Clinical Microbiology \& Infectious Diseases 2011;30,799-805.

27. Zhang DM, Ma MM, Wen WT, et al. Clinical epidemiology and molecular profiling of human bocavirus in faecal samples from children with diarrhoea in Guangzhou, China. Epidemiol Infec 2014;3:1-15.

28. Tymentsev A, Tikunov A, Zhirakovskaia E, et al. Human bocavirus in hospitalized children with acute gastroenteritis in Russia from 2010 to 2012. Infect Genet Evol 2016;37:143-9.

29. Lee EJ, Kim HS, Kim HS, et al. Human Bocavirus in Korean Children with Gastroenteritis and Respiratory Tract Infections. BioMed Res Inter 2016;5.

30. Netshikweta R, Chidamba L, Nadan S, Taylor MB, Page N.Molecular epidemiology of human bocavirus infection in hospitalized children with acute gastroenteritis in South Africa, 2009-2015. J Med Virol. 2020;92:1124-1132.

31. Proenca-Modena JL, Martinez M, Amarilla AA, et al. Viral load of human bocavirus-1 in stools from children with viral diarrhoea in Paraguay. Epidemiol Infect 2013;141(12):2576- 